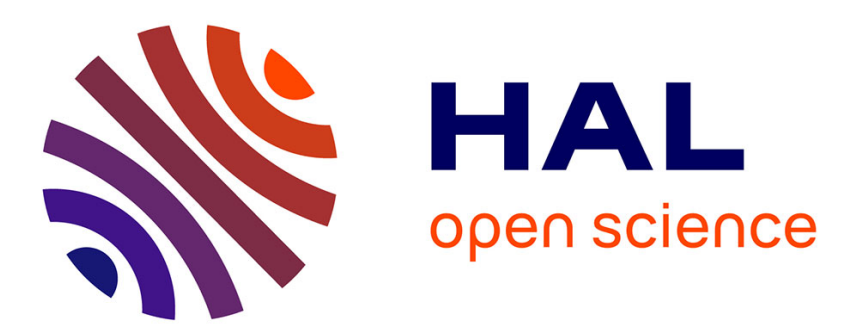

\title{
A life cycle assessment approach to the electricity generation of French overseas territories
}

Vanessa Rakotoson, Jean-Philippe Praene

\section{To cite this version:}

Vanessa Rakotoson, Jean-Philippe Praene. A life cycle assessment approach to the electricity generation of French overseas territories. Journal of Cleaner Production, 2017, 168, pp.755 - 763. 10.1016/j.jclepro.2017.09.055 . hal-01620317

\section{HAL Id: hal-01620317 https://hal.science/hal-01620317}

Submitted on 30 Nov 2017

HAL is a multi-disciplinary open access archive for the deposit and dissemination of scientific research documents, whether they are published or not. The documents may come from teaching and research institutions in France or abroad, or from public or private research centers.
L'archive ouverte pluridisciplinaire HAL, est destinée au dépôt et à la diffusion de documents scientifiques de niveau recherche, publiés ou non, émanant des établissements d'enseignement et de recherche français ou étrangers, des laboratoires publics ou privés. 
A life cycle assessment approach to the electricity generation of French overseas territories

\author{
Vanessa Rakotoson ${ }^{\mathrm{a}}$, Jean Philippe Praene ${ }^{\mathrm{a}}$ \\ vanessa.rakotoson@univ-reunion.fr \\ ${ }^{a}$ Laboratory of Physics and Mathematical Engineering for the study of Energy, Environment and Building, \\ 117 rue du General Ailleret - P.O. Box 97430 Le Tampon - Reunion, France
}

\begin{abstract}
Due to the high reliance on fossil fuels in the electricity production and transport sectors, completing the energy transition holds a particular importance for non-interconnected territories. The environmental impacts from electricity generation are mainly imputed to fossil fuel based technologies, for instance in the case of French insular territories. This paper summarizes the present electricity situation in these territories and aims to determine their different emissions and environmental impacts through a life cycle assessment (LCA) approach. To deliver $1 \mathrm{kWh}$ of electricity to the power grid from the studied regions, the electricity mix is defined as the functional unit. The results refer to a life cycle cradle-to-gate electricity production model. The impact categories discussed in this paper are related to global warming potential, acidification potential, tropospheric ozone precursor potential, and the cumulative energy used. Due to its high share of renewable energies sources, French Guyana has the lowest greenhouse gases (GHG) emissions per kilowatt-hour produced compared to the other islands $\left(373 \mathrm{~g} \mathrm{CO}_{2}\right.$-eq/kWh, $4.29 \mathrm{~g} \mathrm{SO}$-eq/ $\mathrm{kWh}$ and $2.65 \mathrm{~g}$ NMVOC-eq/kWh). Combined with other social, economic and environmental parameters, these results will be also used to determine the typologies of islands in order to define a common energy strategy for each group. Keywords: Electricity generation, Greenhouse gas emission, Life Cycle Assessment, French overseas territories
\end{abstract}

\title{
1. Introduction
}

Electricity production in France shows variation: in 2013, the mainland electricity mix was dominated by $74 \%$ nuclear and $13 \%$ hydroelectric, while French overseas departments and territories have an average coal and oil contribution of $73 \%$ (SOeS, 2015). This high share of fossil fuels in the energy mixes of these territories can be

5 explained by the general disadvantages that insular areas face in relation to their remoteness and size (Erdinc et al., 2015). In order to overcome the environmental challenges in the current French energy transition policy, it is important to have an accurate overview of the existing production. This study seeks to analyze the individual electricity generation influence and the GHG emissions of each French department studied to define the path to 
achieving a low environmental impact in future electricity demand. Section 2 presents the electricity mix for each of the studied territories. Section 3 provides an overview the LCA method and the hypothesis tested. The results of the evaluation of emissions by energy source, energy mix and infrastructure are presented and discussed in Section 4. A classification of the studied territory using socio-economic and environmental criteria is presented in the last section.

\section{Overview of the electricity sector}

In a previous study, Notton provided the geographical locations of power installations in French territories and the average annual generation in 2012 (Notton, 2015). This paper focuses primarily on the following territories for the base year of 2013: Corsica, Guadeloupe, Martinique, Mayotte, French Guyana and Reunion Island. Remoteness implies an increase in the average supply distance of petroleum products. Fuel transportation is a major driving force for $\mathrm{CO}_{2}$ emissions in the global LCA evaluation.

Table 1: Data and assumptions for electricity generation in French insular territories in 2013

\begin{tabular}{|c|c|c|c|c|c|}
\hline Type of energy & $\begin{array}{r}\text { Installed capacity } \\
(\mathrm{MW})\end{array}$ & $\begin{array}{r}\text { Production } \\
(\mathrm{GWh})\end{array}$ & $\begin{array}{r}\text { Share of mix } \\
(\%)\end{array}$ & Fuel origin & $\begin{array}{r}\text { Distance } \\
(\mathrm{km})\end{array}$ \\
\hline \multicolumn{6}{|c|}{ Corsica (EDF-SEI, 2013a, 2014a, Hellion et al., 2008) } \\
\hline Biogas & 1.7 & 11.1 & 0.50 & Local & \\
\hline Heavy Fuel & 186.3 & 529.9 & 23.71 & PACA Region & 491.8 \\
\hline Hydrodam & 181.1 & 522.8 & 23.4 & Local & \\
\hline Hydro ROR & 25.6 & 73.9 & 3.31 & Local & \\
\hline Interconnected & 150 & 663.8 & 29.70 & Italy, Sardinia & \\
\hline \multicolumn{6}{|l|}{ network } \\
\hline Light fuel oil & 105 & 299.1 & 13.39 & PACA region & 491.8 \\
\hline Photovoltaic & 86 & 113.9 & 5.10 & Local & \\
\hline Wind energy & 18 & 20.1 & 0.90 & Local & \\
\hline
\end{tabular}

Guadeloupe (Observatoire Régional de l'énergie et du climat, 2014, EDF-SEI, 2014c) 


\begin{tabular}{|c|c|c|c|c|c|}
\hline Type of energy & $\begin{array}{r}\text { Installed capacity } \\
(\mathrm{MW})\end{array}$ & $\begin{array}{l}\text { Production } \\
\qquad(\mathrm{GWh})\end{array}$ & $\begin{array}{r}\text { Share of mix } \\
\qquad(\%)\end{array}$ & Fuel origin & $\begin{array}{r}\text { Distance } \\
(\mathrm{km})\end{array}$ \\
\hline Bagasse & 59.5 & 46.7 & 2.70 & Local & \\
\hline Biogas & 0.2 & 0.2 & 0.01 & Local & \\
\hline Coal & 93.5 & 539.4 & 31.20 & Colombia & 1483 \\
\hline Geothermal & 11.5 & 81.3 & 4.70 & Local & \\
\hline Heavy fuel oil & 186.0 & 576.8 & 33.36 & Venezuela & 1275 \\
\hline Hydropower & 8.7 & 19.0 & 1.10 & Local & \\
\hline Light fuel oil & 100.0 & 310.1 & 17.94 & Venezuela & 1275 \\
\hline Photovoltaic & 67.4 & 98.5 & 5.70 & Local & \\
\hline Wind energy & 24.4 & 57.1 & 3.30 & Local & \\
\hline \multicolumn{6}{|c|}{ French Guyana (EDF-SEI, 2013b, 2014b) } \\
\hline Biomass & 1.7 & 8.6 & 1.00 & Local & \\
\hline Heavy fuel oil & 67.4 & 167.9 & 19.57 & Trinidad \& Tobago & 1191 \\
\hline Hydropower & 118.1 & 489.1 & 57.00 & Local & \\
\hline Light fuel oil & 60 & 149.5 & 17.43 & Trinidad \& Tobago & 1191 \\
\hline Photovoltaic & 34 & 42.9 & 5.00 & Local & \\
\hline \multicolumn{6}{|c|}{ Martinique (EDF-SEI, 2014d, IEDOM, 2015b) } \\
\hline Biomass & 4 & 15.8 & 1.00 & Local & \\
\hline Heavy fuel oil & 244.2 & 972.6 & 61.67 & Venezuela & 1099 \\
\hline Light fuel oil & 128.8 & 512.9 & 32.53 & Venezuela & 1099 \\
\hline Photovoltaic & 60 & 74.1 & 4.70 & Local & \\
\hline Wind energy & 1.1 & 1.6 & 0.10 & Local & \\
\hline \multicolumn{6}{|c|}{ Mayotte (IEDOM, 2015a) } \\
\hline Heavy fuel oil & 78.1 & 248.1 & 94.71 & Middle-East/India & 5412 \\
\hline Photovoltaic & 11.9 & 13.8 & 5.29 & Local & \\
\hline
\end{tabular}

Reunion (SPL Energies Réunion, 2016, Observatoire Énergie Réunion, 2014) 


\begin{tabular}{|c|c|c|c|c|c|}
\hline Type of energy & $\begin{array}{r}\text { Installed capacity } \\
(\mathrm{MW})\end{array}$ & $\begin{array}{r}\text { Production } \\
\text { (GWh) }\end{array}$ & $\begin{array}{r}\text { Share of mix } \\
\qquad(\%)\end{array}$ & Fuel origin & $\begin{array}{r}\text { Distance } \\
(\mathrm{km})\end{array}$ \\
\hline Bagasse & 210.0 & 251.4 & 8.94 & Local & \\
\hline Biogas & 2.9 & 14.9 & 0.53 & Local & \\
\hline Coal & 210.0 & 1267.6 & 45.06 & South Africa & 4000 \\
\hline Heavy fuel oil & 211.0 & 290.5 & 10.32 & Malta & 9500 \\
\hline Hydropower & 133.6 & 557.0 & 19.80 & Local & \\
\hline Light fuel oil & 140.0 & 192.7 & 6.85 & Singapour & 7000 \\
\hline Photovoltaic & 160.2 & 224.2 & 7.97 & Local & \\
\hline Wind energy & 14.8 & 15.1 & 0.54 & Local & \\
\hline
\end{tabular}

As can be seen in Fig. 1 and Table 1, only Corsica benefits from the network interconnection with Sardinia, which plays an important role in the supply/demand balance, particularly during high consumption periods. Martinique and Mayotte represent the French overseas territories (FOTs) that are the least developed in terms of renewable energy sources (RES) in the electricity mix, with $95 \%$ of fossil-fuel and $5 \%$ of RES. The difference between the two situations lies in the contribution of wind energy and biogas production in Martinique. Recognizing their high potential for RES, Guadeloupe and Reunion diversified their mixes by integrating hydropower, solar energy, geothermal energy, biogas and bagasse (Praene et al., 2012, ADEME, 2014). However, the RES component of Guadeloupe's generation is half that of Reunion's. French Guyana is the only territory that has used 63\% RES for its electricity production, mainly using hydroprower. Data in Table 1 will be used for the electricity generation GHG emissions assessment. 


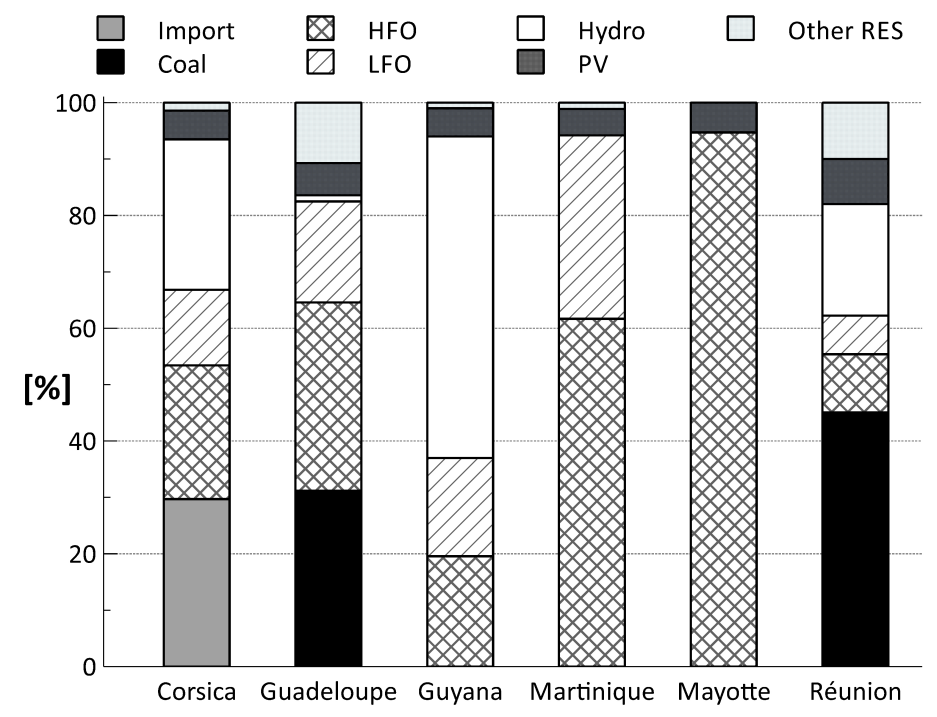

Figure 1: Overview of the energy sources in the studied departments' electricity mixes. HFO: Heavy fuel oil; LFO: Light fuel oil. Other RESs include bagasse, biogas, biomass, and wind energy production.

\section{Materials and methods}

To date, a significant number of LCA analyses examining electricity generation technologies (EGTs) at different levels are available in the literature. (Asdrubali et al., 2015), (Turconi et al., 2013) and (Jacobson, 2009) proposed an overview and a harmonization of LCA results from EGTs in order to provide a range of values of GHG emissions for each technology. Studies provide range of values of GHG emission for different technology : (Asdrubali et al., 2015) gives an overview of LCA results of renewable technologies (RETs), (Turconi et al., 2013) focused on 167 studies to provide a basis for making choices on technology and methodology approach. A comparison of the environmental impacts of fossil fuel-based technologies (FFTs) are presented by (Atilgan and Azapagic, 2015) in Turkey and (Tan et al., 2010) in Singapore. (Ramjeawon, 2008) presents LCA results of electricity from bagasse in Mauritius, and (Silva et al., 2012) in Brazil.Comparisons between FFTs and RETs performed by (Hondo, 2005) in Japan or (Smith et al., 2015) in Singapore, can help select the most appropriate technologies for an electricity generation system.Papers also provide LCA results by country, as Mexico (Santoyo-Castelazo et al., 2011), Portugal (Garcia et al., 2014) or Greece (Theodosiou et al., 2014). (Herbert et al., 2016) developed a series of GHG emissions assessments for selected countries, from which four types of countries were identified. However, few papers concern islands (Brizmohun et al., 2015). This study will provide an initial evaluation of the environmental burdens of electricity generation in these FOTs and will enrich the literature review on LCA studies on insular territories. This work is conducted within 
the framework of cleaner production, because it shows the current status of the production mode of electricity in the French overseas territories. It helps to understand which part of the life cycle stage contributes the most in the greenhouse gases emissions. The energy balance report for Reunion in 2014 provided a comparison of FOTs by in the electricity and transport sectors (SPL Energies Réunion, 2015). However, the assessment methodology and the assumptions used are not explicitly mentioned.

\subsection{Scope and system boundary}

In this study, LCA is used to identify the environmental burdens and impacts throughout the electricity generation process. The LCA methodology applied here is regulated by ISO standards 14040 and 14044 (International Standards Organisation, 2006a,b). The study boundaries are from cradle-to-gate, including acquisition, transportation, infrastructure construction and electricity production. Transportation concerns the port-to-port carriage of direct-use energy. Fig. 2 represents the boundaries considered in energy production. The functional unit (FU) is defined by 1 kilowatt-hour produced; in the rest of the document, we will denote an FU as 1 kWhe.

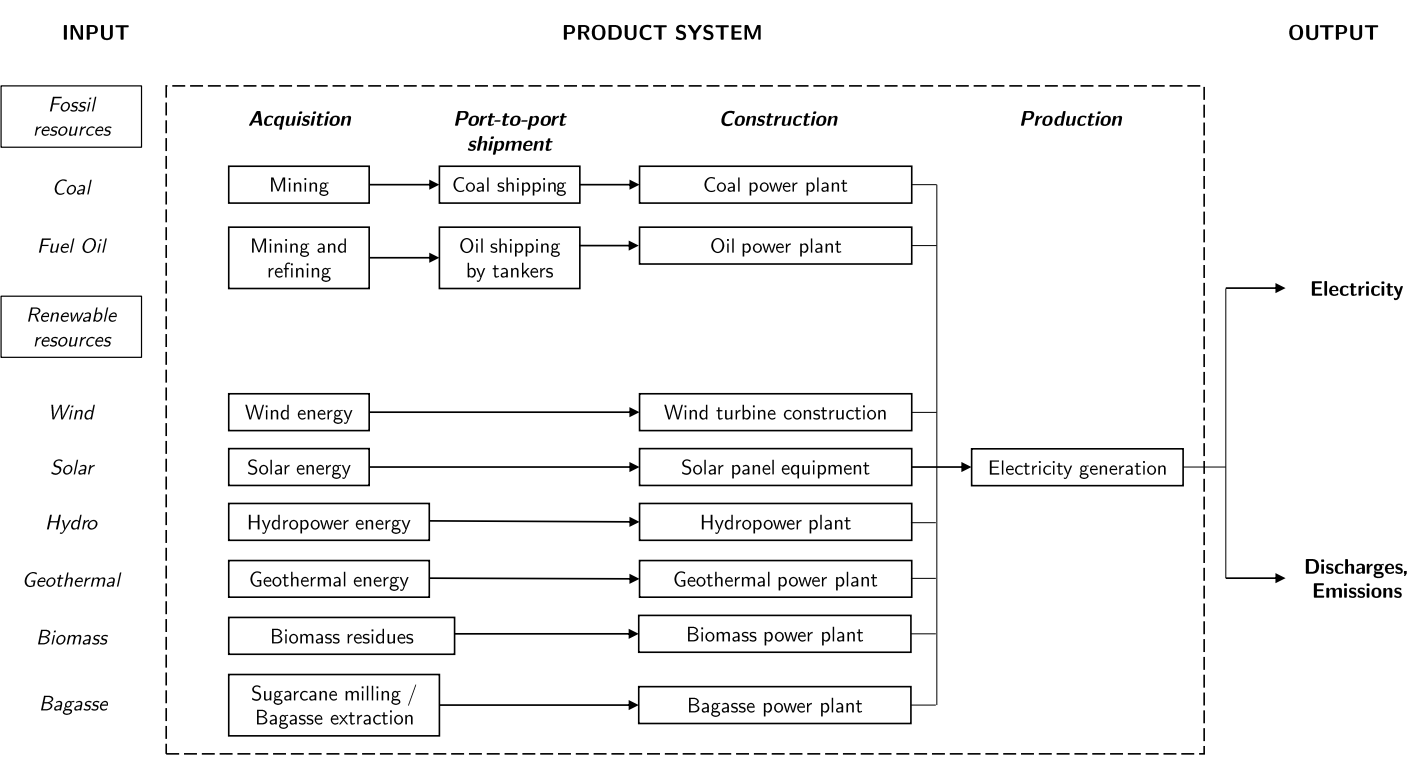

Figure 2: Cradle-to-gate life cycle stages of the electricity production system (modified from (Gujba et al., 2010) and (Brizmohun et al., 2015)) 
To identify the potential impacts, standard LCA software GEMIS version 4.9 and its database have been used and adapted here (Öko-Institut, 2015). Due to the lack of information about the efficiency of each power plant, the GEMIS database has been used. However, parameters such as transportation, scale, power generated have been adapted to the islands' conditions as a lack of information on islands' technologies has been identified as a limitation

65 of the software. The proposed tool has been implemented in a MATLAB environment in order to link the LCA results from GEMIS software to an another energy scenario tool in a unique environment. Results can be treated as a method to highlight the most emissive life-cycle stage and also can be used as constraints in future scenario modeling research.

The MATLAB code was developed in two parts. First, GEMIS provides the data emissions of each electricity generation, through its life cycle: raw materials extraction and its necessary quantities to produce $1 \mathrm{kWh}$ electricity, the existing means of transport, the infrastructure construction and the production. These data are then manipulated in MATLAB. Second, in line with the LCA methodology, several inputs are required: the total electricity production, the installed capacity, the distance of the raw material supply, and the mean of transport used. These data help to determine the quantity of the raw materials, the adapted emission factor (EF) related to the size of the installed power plant, and indicates the remoteness of the territory. The total emission $E_{T o t}$ of the electricity mix of the studied territory is obtained by Eq.1

$$
E_{T o t}=\sum_{i=1}^{n} E_{e x t, i}+E_{t r a n s, i}+E_{c o n s, i}+E_{\text {prod }, i}
$$

where $E_{\text {ext }}$ is the emission of raw materials extraction, $E_{\text {trans }}$ the emission of the raw materials transport, $E_{\text {cons }}$ the emission due to the construction plant, $E_{\text {prod }}$ the emission due to the production operation, and $i$ represents each power plant. For each technology and life-cycle stage inventory, the calculation of emission is based on the Eq.2 principle :

$$
E_{l c s}=\sum_{i=1}^{n} E F_{i} \times q_{p, i}
$$

where $E$ represents the emission value of the life cycle stage (extraction, construction, transport and production), EF the corresponding EF for $1 \mathrm{FU}$ of the life-cycle stage and $q_{p}$ the quantity of the product expressed in the FU. Fig. 3 illustrates the methodology used in this work and shows which parameters are considered in the power system to evaluate the different potential environmental impacts. 


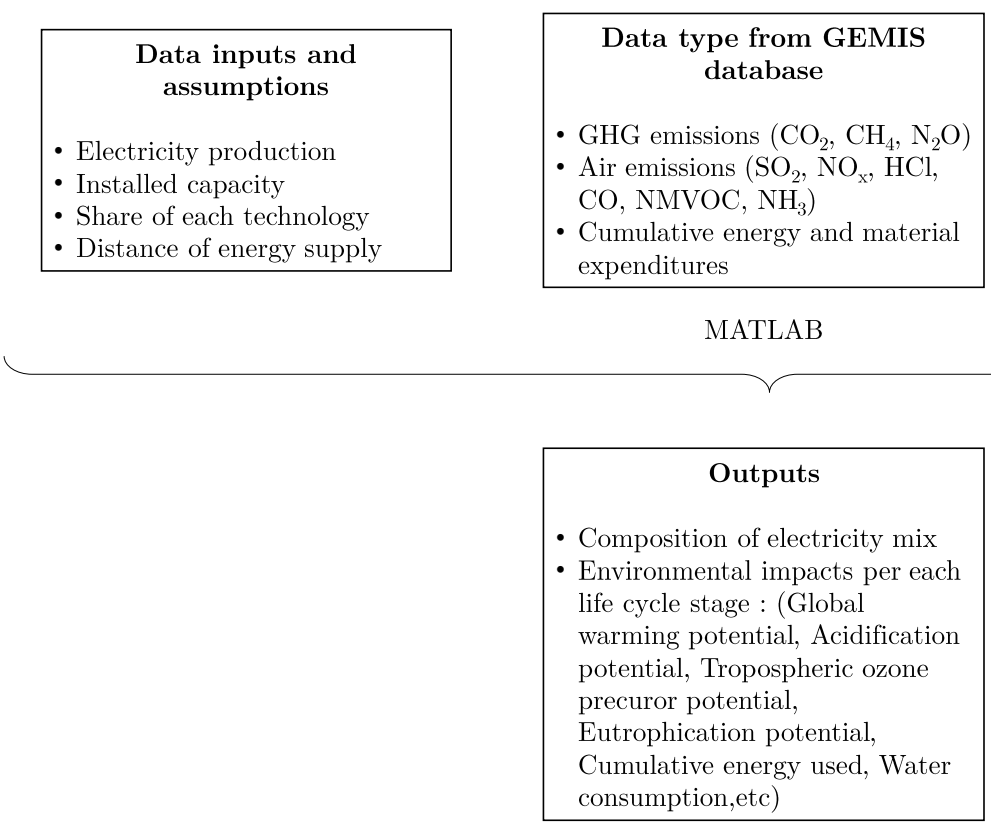

Figure 3: Methodology and data used to assess the potential environmental impacts combining GEMIS, the LCA methodology and MATLAB

\section{Results and discussion}

\subsection{Selected environmental burdens}

An LCA study generally highlights different indicators grouped into four major categories: climate change, ecosystem quality, human health and resource depletion. Instead, we choose to present a sampling of indicators that represents each category, which are the most representative of each impact category: global warming potential (GWP), acidification potential (AP), tropospheric ozone precursor potential (TOPP) and cumulative energy use $(\mathrm{CEU})$. 

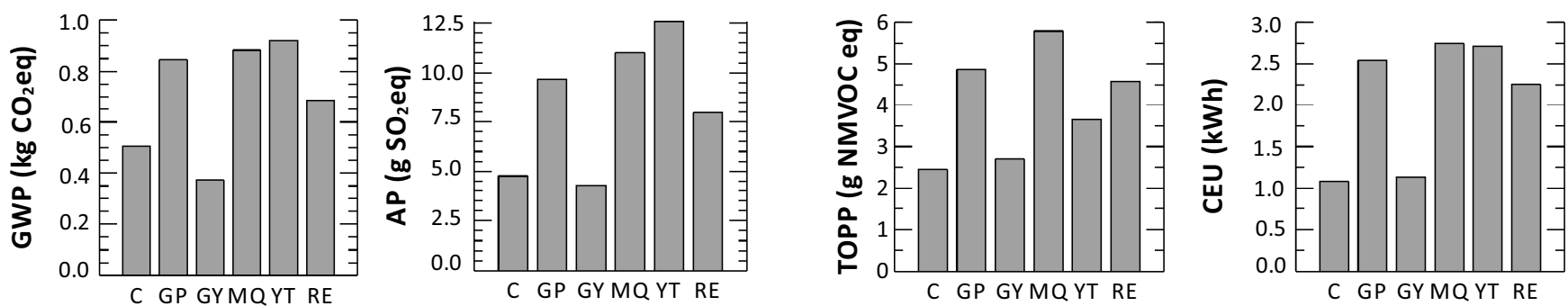

Figure 4: Environmental impacts from 1 kWhe produced [C: Corsica, GP: Guadeloupe, GY: French Guyana, MQ: Martinique, YT: Mayotte, RE: Reunion]

Fig. 4 shows the results obtained for the different indicators: Mayotte records the highest levels of GWP and $\mathrm{AP}$ and requires the most energy used to produce $1 \mathrm{kWhe}$ after Martinique. The general pattern of the other environmental impacts is much the same.

\subsection{Global warming potential (GWP)}

Regarding to the results in Fig. 4, Mayotte produces the highest amount of GWP emissions with $0.921 \mathrm{~kg}$ $\mathrm{CO}_{2}$-eq/kWhe, followed by Martinique $(0.883 \mathrm{~kg} \mathrm{CO}$-eq/kWhe) and Guadeloupe (0.846 $\mathrm{kg} \mathrm{CO}$-eq/kWhe). These results are explained by the massive use of fossil-fuel sources in these territories (see Fig. 1). Reunion generated about $0.687 \mathrm{~kg} \mathrm{CO}-\mathrm{eq} / \mathrm{kWh}$. Through the extensive use of RES and the network interconnection, Corsica and French Guyana emit fewer pollutants than the other territories, with 0.505 and $0.373 \mathrm{~kg} \mathrm{CO}_{2}$-eq/kWhe, respectively. The values obtained in this study are slightly below those on the energy balance report for Reunion (SPL Energies Réunion, 2015). This can be explained by the considered boundaries for the assessment that might not to be the same. In Fig. 5-a, we can see that the production phase contributes greatly to each $1 \mathrm{kWhe}$ produced for each island, representing $95 \%$ of the total emissions for every $1 \mathrm{kWhe}$ produced. In Fig. 5 -b, it is apparent that the extraction and transportation phase are mostly generated by fossil energies. Mayotte recorded the highest value for the extraction phase due to its high share of petroleum products. We can also see that the most significant value for fossil fuel transportation is recorded by Reunion, followed by Mayotte, a result that is explained by these islands' coal and fossil fuel supplies. Thus, these transportation results show that these two islands are more isolated than the others with regard to the distance of energy supply. French Guyana's emission records the lowest value in each phase except in power plant construction. With the understanding that hydropower composes $57 \%$ of the electricity mix and more than $75 \%$ of the construction emissions, we can deduce that the construction of renewable energy infrastructure is 
more emissive than that of other power sources. For Mayotte, the construction of photovoltaic panels generates more emissions than the construction of conventional sources.

\subsection{Other impacts}

As with GWP, the operation of FFTs is mainly responsible for the majority of the other impacts (Fig. 5). This is briefly discussed in the following paragraphs.

Acidification potential (AP). As presented in the preceding section, we discuss here the contribution of each power plant to the AP that it generates when producing $1 \mathrm{kWhe.} \mathrm{It} \mathrm{can} \mathrm{be} \mathrm{seen} \mathrm{in} \mathrm{Fig.} 4$ that Mayotte has the highest AP value, followed by Martinique and Guadeloupe. As can be seen in Fig. 5-d, the main contributor in Reunion is the operation of the coal power plant $(67 \%)$. On the other islands, fuel oil power plants contribute at least $61 \%$, as in Guadeloupe, followed by coal (35\%). In general, hydropower and solar panels do not exceed $1 \%$ of the total contribution in acidification potential.

Tropospheric ozone precursor potential (TOPP). TOPP is the mass-based equivalent of the ozone formation rate from precursors, measured in ozone precursors equivalents. The TOPP represents the potential formation of nearground (tropospheric) $\mathrm{O}_{3}$, which can cause summer smog (Öko-Institut, 2015). The distribution of the contributions of each power plant to TOPP emissions is quite similar to that for AP emissions (see Fig. 5-e and f). However, Martinique recorded the highest value of TOPP emissions produced per $1 \mathrm{kWhe}(0,0057 \mathrm{~g}$ NMVOC eq), followed by Guadeloupe and Reunion.

Cumulative energy use (CEU). The CEU represents the expenditure of energy resources (primary energies) for the production of $1 \mathrm{kWhe.} \mathrm{As} \mathrm{can} \mathrm{be} \mathrm{seen} \mathrm{in} \mathrm{Fig.} \mathrm{4,} \mathrm{Martinique} \mathrm{and} \mathrm{Mayotte} \mathrm{require} \mathrm{the} \mathrm{highest} \mathrm{values} \mathrm{of} \mathrm{CEU,} \mathrm{which}$ is explained by the high proportion of fossil energies in their electricity mixes. They are followed by Guadeloupe and Reunion, which show fairly diversified electricity mixes. 

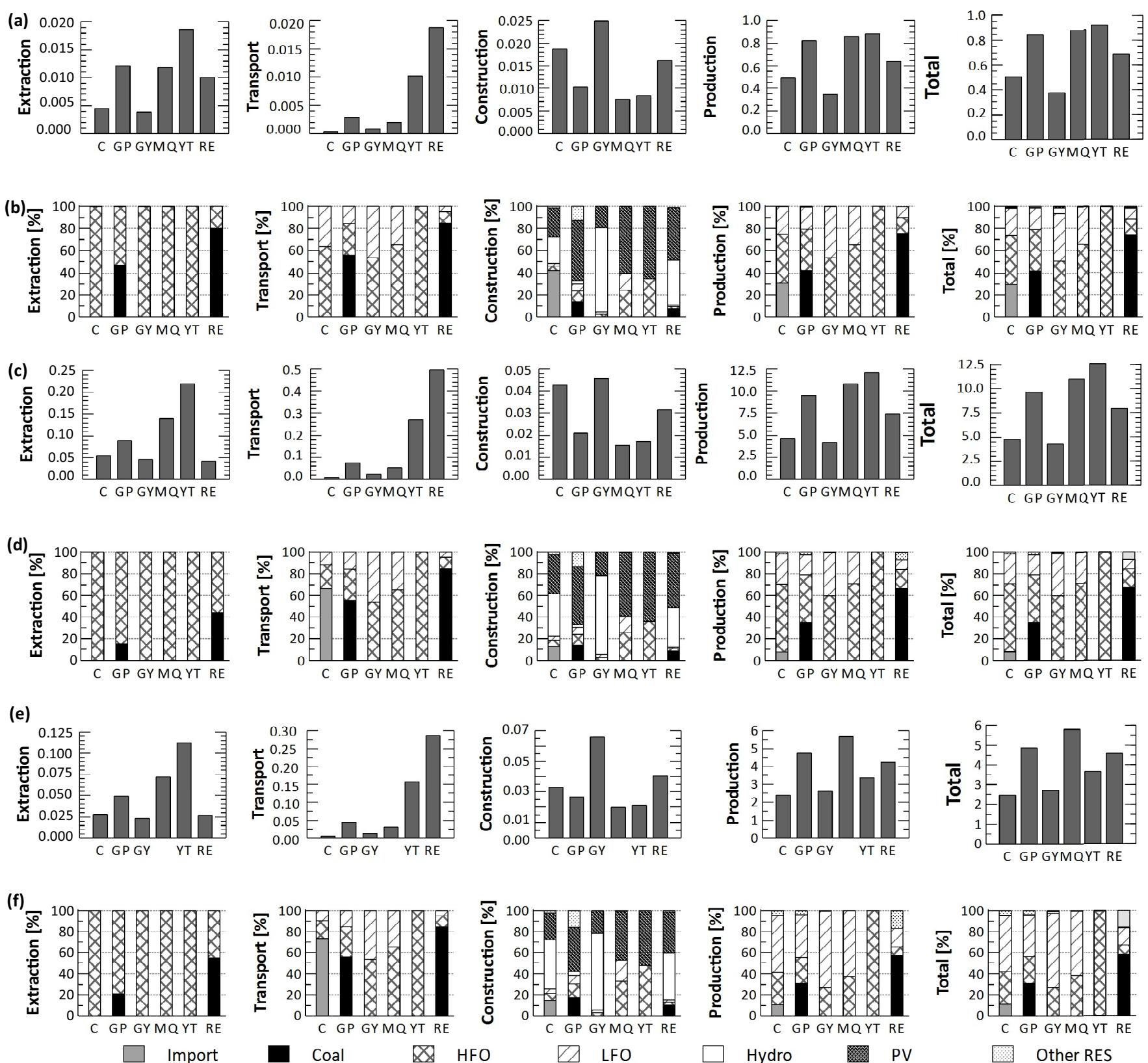

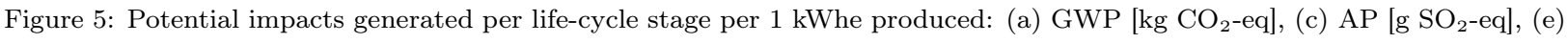
TOPP [g NMVOC-eq]. Share of each technology at life cycle stage: (b) GWP, (d) AP, (f) TOPP

From the results above, the FOTs can be classified using the typology of countries proposed by (Herbert et al., 2016). This study proposed 4 types of electricity mixes that differ from one another in the major energy production type and GWP value. Considering the existing groups as presented in Table 2, Guyana and Corsica belong to the 
third group, characterized by average values of GHGs (300-600 $\mathrm{g} \mathrm{CO}_{2}$-eq). The remainder of the territories belong to the fourth group, in which energy mix composition is mainly composed of FFTs. However, even if Reunion is assumed to be withingroup 4, Reunion lies within the transition zone between groups 3 and 4: its electricity mix is mainly composed of coal and oil, and the remaining production is diversified.

From a national overview, FOTs contribute at a low level in the national electricity consumption, about $1.9 \%$ of the total amount of electricity consumption, including mainland and overseas territories and region. However, the emission factor of electricity in France in 2013 is about $84 \mathrm{~g} \mathrm{CO}_{2} \mathrm{eq} / \mathrm{kWh}$, according to ADEME's value (ADEME, 2013), and the other territories record an emission electricity factor about 4 to 11 times higher than those of mainland.

Table 2: Classification of the FOT using the world mix typology based on (Herbert et al., 2016)

\begin{tabular}{|c|c|c|c|c|c|}
\hline \multirow[t]{2}{*}{ Group } & \multirow[t]{2}{*}{ Territories } & \multirow[t]{2}{*}{ GHG } & \multirow{2}{*}{$\begin{array}{l}\text { Bounds } \\
\left(\mathrm{g} \mathrm{CO}_{2} \mathrm{eq} / \mathrm{kWh}\right)\end{array}$} & \multicolumn{2}{|c|}{ Main characteristics } \\
\hline & & & & Major production & Other production \\
\hline 1 & & Very low & $0-37$ & Hydroelectric and/or nuclear & Predominantly renewables \\
\hline 2 & France & Low & $37-300$ & Hydroelectric and/or nuclear & Diversification \\
\hline 3 & French Guyana, Corsica & Average & $300-600$ & Gas & Diversification \\
\hline 4 & Reunion, Guadeloupe, & High & $>600$ & Coal, oil & Predominantly fossils \\
\hline & Martinique, Mayotte & & & & \\
\hline
\end{tabular}

\section{Principal component analysis (PCA)}

The previous results allow us to establish the first classification of FOTs in the global context. A PCA has been performed to investigate these islands regarding the following key data: population, GDP per capita, annual electricity production, RES share in the electricity mix, total GWP emissions from electricity production, area and the insulation situation index (ISI), as obtained from (Delaître et al., 2008). The objective was to identify the similarities between the overseas territories, particularly from the perspective of renewables. Table 3 gives an overview of the parameters considered in the PCA. 
Table 3: Geographical and economic situation, electricity production and the environmental burdens of the FOT

\begin{tabular}{|c|c|c|c|c|c|c|c|}
\hline Location & Population & $\begin{array}{r}\text { GDP } \\
\text { per capita } \\
\text { [€/capita] }\end{array}$ & $\begin{array}{l}\text { Electricity } \\
\text { production } \\
\text { [GWh] }\end{array}$ & $\begin{array}{r}\text { Share of RES } \\
\text { (SHREN) } \\
{[\%]}\end{array}$ & $\begin{array}{r}\text { GWP } \\
{[\mathrm{kg} \mathrm{CO}-\mathrm{eq}} \\
/ \mathrm{kWh}]\end{array}$ & $\begin{array}{l}\text { Area } \\
{\left[\mathrm{km}^{2}\right]}\end{array}$ & ISI \\
\hline Corsica & 319,780 & 25,523 & 2235 & 32.71 & 0.505 & 8680 & 0.55 \\
\hline Guadeloupe & 41,1507 & 20,072 & 1729 & 17.51 & 0.846 & 1704 & 61.2 \\
\hline French Guyana & 23,7550 & 15,820 & 858 & 63 & 0.373 & 86,504 & 100.32 \\
\hline Martinique & 381,326 & 22,266 & 1577 & 5.8 & 0.883 & 1128 & 83.1 \\
\hline Mayotte & 211,397 & 7896 & 261.90 & 5.29 & 0.921 & 374 & 71.5 \\
\hline Reunion & 840,974 & 19,340 & 2813.4 & 37.78 & 0.687 & 2512 & 20.6 \\
\hline
\end{tabular}

Once the correlation matrix was calculated, it was shown that the chosen criteria are not correlated, except the RES proportion and the GWP value. The negative correlation between these two parameters is explained by the fact that GWP emissions levels decline with the increase of RES. Area is also negatively correlated to GWP. Indeed, if the island is too small, there are likely fewer opportunities to produce electricity cleanly. The bar plot of the percentage of variance allows to assess the projection quality. Fig. 6 shows that Dimensions 1 and 2 explain $82 \%$ of the variance (see Table A.1), which is a sufficient quality projection for the analysis.

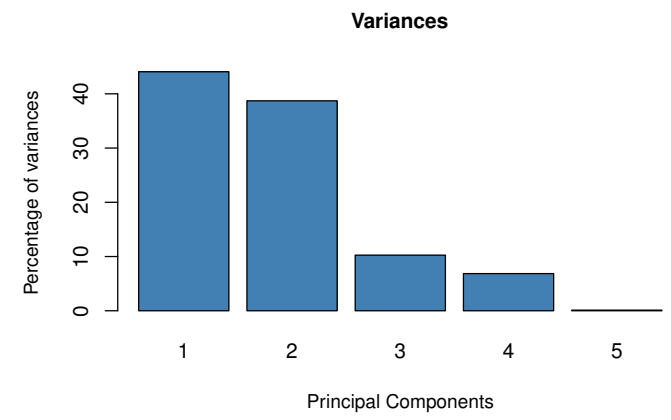

Figure 6: Scree plot of the eigenvalues 


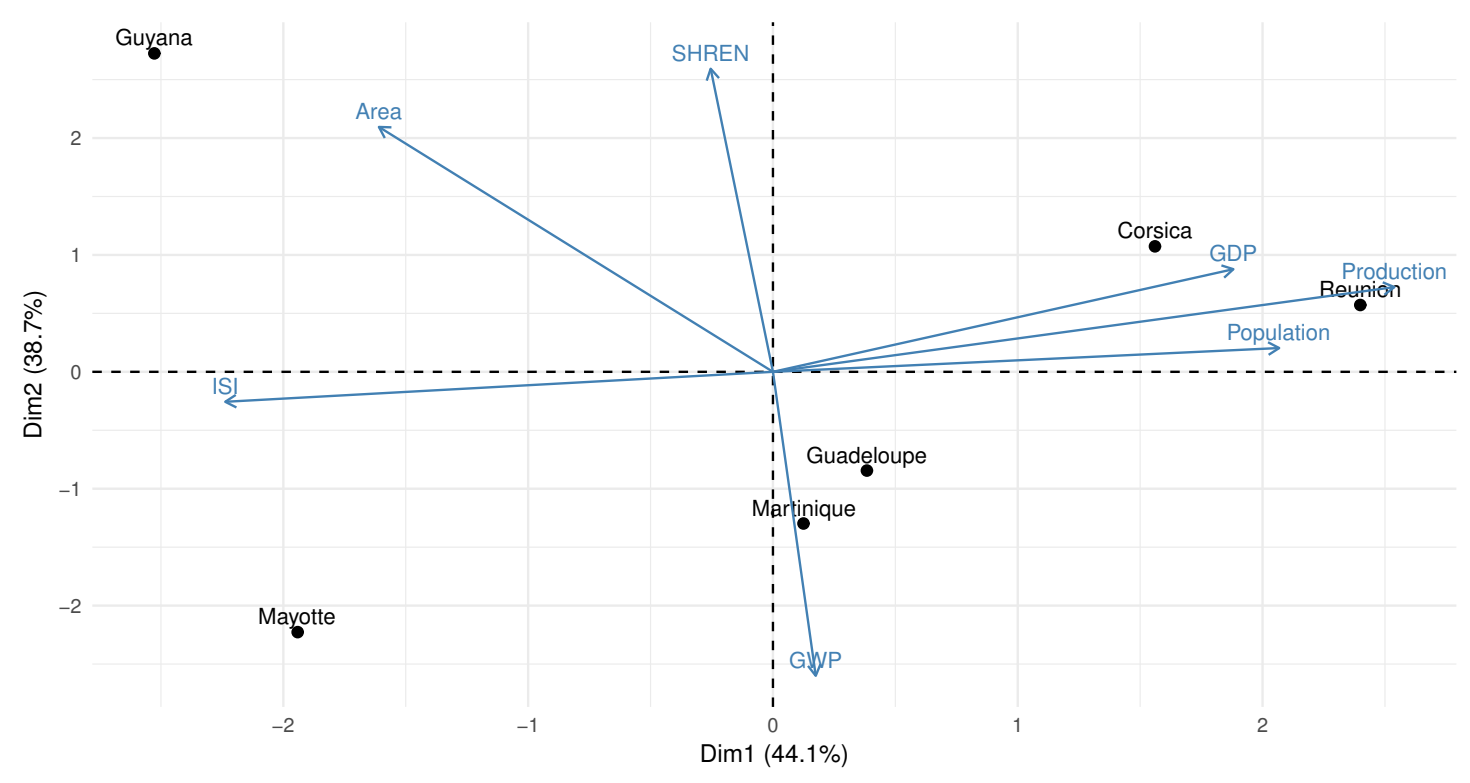

Figure 7: Principal component analysis: a biplot of variables and individuals factor maps

Based on the PCA results obtained from the package FactoMineR in the R statistical package (Lê et al., 2008), Fig. 7 presents a combination of the individuals' and variables' factor maps. Considering the factorial design, the projection qualities of the individuals are assessed by the total value of the square cosine on the two axes. The higher the square cosine value is, the better the projection quality is. Table A.2 shows that all the individuals have a square cosine value on the two axes above 0.600, except for Martinique, which records a total square cosine of 0.531 . Considering Table A.3, all variables present a total square cosine above 0.600 , including the individuals results.

The contribution to the construction of the axis is an another indicator of the projection quality. Based on the results, the electricity production contribution is the highest for the Dimension 1, followed by the ISI. The GWP emission and the percentage of RES in the mix contribute about $70 \%$ of Dimension 2 in the variable factor map. The PCA projection shows high dependencies among the variables Production, Population, GDP and ISI. For the individual projections, French Guyana and Mayotte contribute highly to the construction of the second axis, $45 \%$ and $30 \%$ respectively. The negative correlation between GWP emission and RES contribution is well represented in Fig. 7 in the variable factor map, as is the case of the ISI parameter and electricity production. These results allow us to identify two types of territories and two singular cases:

- Corsica and Reunion Island represent islands that have a high electricity production with large populations and a high GDP, and their electricity mix involves a relatively high proportion of RES (>30\%); 
- Guadeloupe and Martinique represent islands with a high fossil-fuel electricity generation. This could be explained by the small area and the ISI of these islands. The lack of hydropower plants on both highlights the small area and topographical variability;

- French Guyana is a large territory with an electricity mix mainly based on hydropower and a high degree of isolation;

- Mayotte is a small remote island, which explains the high GWP value for its electricity generation.

The PCA highlighted that electricity generation and its production modes are significant parameters that help characterize an island's remoteness and its predisposition to using fossil fuels. The ISI factor is also very important in the understanding of fossil-fuel source use in place of RES in the electricity mix.

\section{Conclusion}

The present study was designed to determine the effects of insularity on the electricity production on islands. Although this study focuses on environmental impact assessment using LCA methodology, it also allowed for the development of an evaluation tool based on LCA in the MATLAB environment that will be linked to an energy forecast and scenario tool in future works. The LCA results will be taken as constraints in energy scenarios or, alternatively, the developed scenario will be evaluated through LCA in one combined tool. In this study, the results obtained identify Mayotte and Martinique as the islands that generated the most emissions for each indicator, particularly for GWP and CEU. It was also shown that operation-production generates the most GHG emissions. For each studied territory, we have identified which energy sources generates the most GHG emissions. This study shows that RES shares in GHG emissions are very low, and their contribution is only significant in infrastructure construction. According to their geographic location, territories like these islands should promote the use of RES in their electricity production in order to reduce GHG emissions. This study has also allowed us to identify, among the French overseas territories, two types of islands: for the two groups, one with Reunion and Corsica and the other with Guadeloupe and Martinique, similar energy transition scenarios can be designed in future works. Mayotte and French Guyana will be studied individually. This study has also led to positioning the FOTs in an international context through their GWP values. The PCA also highlights the influence of electricity production types in the classification of these non-interconnected territories. It seems that integrating an environmental index like as $\mathrm{gCO}_{2}$-eq per $\mathrm{kWh}_{\mathrm{W}}$ electricity into scenario projections would be helpful. Such an index represents an encapsulation of information that 
was previously contained in two factors, electricity production and RES share. This study helps in understanding which factors must be observed for future energy planning investigations. These key factors could be integrated in scenario modeling as constraints.

\section{Acknowledgments}

This research received financial support from Reunion Region and the European Union - The European Regional

Development Fund, within the context of the Territorial Cooperation Operational Programme.

\section{Appendix}

PCA results.

\begin{tabular}{l|rrrrr}
\multicolumn{7}{c}{ Table A.1: Eigenvalues } & & & \\
& Dim.1 & Dim.2 & Dim.3 & Dim.4 & Dim.5 \\
\hline Variance & 3.085 & 2.710 & 0.718 & 0.480 & 0.008 \\
Percentage of variance & 44.071 & 38.712 & 10.255 & 6.852 & 0.111 \\
Cumulative percentage of variance & 44.071 & 82.782 & 93.038 & 99.889 & 100.000
\end{tabular}

Table A.2: Results for the individual territories (coordinates, square cosine and contributions)

\begin{tabular}{l|rrr|rrr|rrr} 
Individuals & Dim.1 & ctr & cos2 & Dim.2 & ctr & cos2 & Dim.3 & ctr & $\cos 2$ \\
\hline Corsica & 1.561 & 13.157 & 0.407 & 1.074 & 7.088 & 0.192 & -1.356 & 42.660 & 0.307 \\
Guadeloupe & 0.384 & 0.796 & 0.136 & -0.845 & 4.390 & 0.657 & -0.136 & 0.431 & 0.017 \\
French Guyana & -2.527 & 34.498 & 0.459 & 2.724 & 45.651 & 0.533 & 0.225 & 1.175 & 0.004 \\
Martinique & 0.125 & 0.084 & 0.005 & -1.298 & 10.357 & 0.526 & -0.493 & 5.646 & 0.076 \\
Mayotte & -1.942 & 20.365 & 0.390 & -2.227 & 30.504 & 0.513 & 0.328 & 2.502 & 0.011 \\
Reunion & 2.399 & 31.100 & 0.707 & 0.572 & 2.010 & 0.040 & 1.432 & 47.587 & 0.252
\end{tabular}


Table A.3: Results for the variables (coordinates, square cosine and contributions)

\begin{tabular}{l|rrr|rrr|rrr} 
Variables & Dim.1 & ctr & cos2 & Dim.2 & ctr & $\cos 2$ & Dim.3 & ctr & $\cos 2$ \\
\hline GWP & 0.066 & 0.139 & 0.004 & -0.975 & 35.078 & 0.951 & 0.130 & 2.355 & 0.017 \\
Population & 0.775 & 19.483 & 0.601 & 0.076 & 0.215 & 0.006 & 0.610 & 51.770 & 0.372 \\
GDP & 0.705 & 16.118 & 0.497 & 0.329 & 3.999 & 0.108 & -0.511 & 36.358 & 0.261 \\
Production & 0.952 & 29.357 & 0.906 & 0.272 & 2.727 & 0.074 & 0.062 & 0.533 & 0.004 \\
SHREN & -0.095 & 0.295 & 0.009 & 0.972 & 34.875 & 0.945 & 0.198 & 5.487 & 0.039 \\
Area & -0.603 & 11.805 & 0.364 & 0.785 & 22.766 & 0.617 & 0.067 & 0.622 & 0.004 \\
ISI & -0.839 & 22.804 & 0.703 & -0.096 & 0.341 & 0.009 & 0.144 & 2.876 & 0.021
\end{tabular}

\section{References}

ADEME, 2013. ADEME - Site Bilans GES. URL: http://bilans-ges.ademe.fr/. [in French]. Accessed in Aout 2017.

ADEME, 2014. Emission factor documentation of the Base Carbone $®$ - Version 11.0.0 [in French]. Technical Report. France.

Asdrubali, F., Baldinelli, G., D'Alessandro, F., Scrucca, F., 2015. Life cycle assessment of electricity production from renewable energies: Review and results harmonization. Renewable and Sustainable Energy Reviews 42, 1113-1122. doi:10.1016/j.rser.2014.10.082.

Atilgan, B., Azapagic, A., 2015. Life cycle environmental impacts of electricity from fossil fuels in Turkey. Journal of Cleaner Production 106, 555-564. doi:10.1016/j.jclepro.2014.07.046.

Brizmohun, R., Ramjeawon, T., Azapagic, A., 2015. Life cycle assessment of electricity generation in Mauritius. Journal of Cleaner Production 106, 565-575. doi:10.1016/j.jclepro.2014.11.033.

Delaître, J., Eck, J.V., Malidin, A.S., Reynaud, C., 2008. Caractériser l'énergie dans les îles, in: Iles et énergie : un paysage de contrastes - Guerassimoff, Gilles Maïzi, Nadia, pp. 11-61. [in French].

EDF-SEI, 2013a. Forecast of the electricity supply-demand balance - Corsica. [in French]. Technical Report. EDF Systèmes énergétiques insulaires. Corsica.

EDF-SEI, 2013b. Forecast of the electricity supply-demand balance - French Guyana. [in French]. Technical Report. EDF Systèmes énergétiques insulaires. French Guyana.

EDF-SEI, 2014a. Forecast of the electricity supply-demand balance - Corsica. [in French]. Technical Report. EDF Systèmes énergétiques insulaires. Corsica.

EDF-SEI, 2014b. Forecast of the electricity supply-demand balance - French Guyana. [in French]. Technical Report. EDF Systèmes énergétiques insulaires. French Guyana. 
EDF-SEI, 2014c. Forecast of the electricity supply-demand balance - Guadeloupe. [in French]. Technical Report. EDF Systèmes énergétiques insulaires. Guadeloupe.

EDF-SEI, 2014d. Forecast of the electricity supply-demand balance - Martinique. [in French]. Technical Report. EDF Systèmes énergétiques insulaires. Martinique.

Erdinc, O., Paterakis, N.G., Catalão, J.P., 2015. Overview of insular power systems under increasing penetration of renewable energy sources: Opportunities and challenges. Renewable and Sustainable Energy Reviews 52, 333-346. doi:10.1016/j.rser.2015.07.104.

Garcia, R., Marques, P., Freire, F., 2014. Life-cycle assessment of electricity in Portugal. Applied Energy 134, 563-572. doi:10.1016/j.apenergy.2014.08.067.

Gujba, H., Mulugetta, Y., Azapagic, a., 2010. Environmental and economic appraisal of power generation capacity expansion plan in Nigeria. Energy Policy 38, 5636-5652. doi:10.1016/j.enpol.2010.05.011.

Hellion, V., Salini, P., Bellini, J., Thill, M., 2008. Energy balance and greenhouse gases emission inventory of Corsica [in French]. Technical Report. ADEME Corse/OEC. Corsica.

Herbert, A.S., Azzaro-Pantel, C., Le Boulch, D., 2016. A typology for world electricity mix: Application for inventories in Consequential LCA (CLCA). Sustainable Production and Consumption 8, 93-107. doi:10.1016/j.spc.2016.09.002

Hondo, H., 2005. Life cycle GHG emission analysis of power generation systems: Japanese case. Energy 30, $2042-2056$. doi:10.1016/j.energy.2004.07.020.

IEDOM, 2015a. Annual Rapport 2014 - Mayotte. [in French]. Technical Report. Institution d'Emission des départements d'outre-mer. Mayotte.

IEDOM, 2015b. Annual Rapport 2014 - Martinique [in French]. Technical Report. Institution d'Emission des départements d'outre-mer. Martinique.

International Standards Organisation, 2006a. ISO 14040 Environmental management - Life cycle assessment - Principles and framework.

International Standards Organisation, 2006b. ISO 14044 : Environmental management - Life cycle assessment - Requirements and guidelines.

Jacobson, M.Z., 2009. Review of solutions to global warming, air pollution, and energy security. Energy Environ. Sci. 2, 148-173. doi:10.1039/B809990C.

Lê, S., Josse, J., Husson, F., 2008. FactoMineR: A package for multivariate analysis. Journal of Statistical Software 25, 1-18. doi:10.18637/jss.v025.i01.

Notton, G., 2015. Importance of islands in renewable energy production and storage: The situation of the French islands. Renewable and Sustainable Energy Reviews 47, 260-269. doi:10.1016/j.rser.2015.03.053.

Observatoire Énergie Réunion, 2014. Energy balance of Reunion Island 2013. [in French] . Technical Report. Reunion.

Observatoire Régional de l'énergie et du climat, 2014. Key energy data in Guadeloupe - 2013 [in French]. Technical Report. 
Guadeloupe.

Öko-Institut, 2015. Global Emissions Model of Integrated Systems (GEMIS), version 4.9.

Praene, J.P., David, M., Sinama, F., Morau, D., Marc, O., 2012. Renewable energy: Progressing towards a net zero energy island, the case of Reunion Island. Renewable and Sustainable Energy Reviews 16, 426-442. doi:10.1016/j.rser.2011.08.007.

Ramjeawon, T., 2008. Life cycle assessment of electricity generation from bagasse in Mauritius. Journal of Cleaner Production 16, 1727-1734. doi:10.1016/j.jclepro.2007.11.001.

Santoyo-Castelazo, E., Gujba, H., Azapagic, A., 2011. Life cycle assessment of electricity generation in Mexico. Energy 36, 1488-1499. doi:10.1016/j.energy.2011.01.018.

Silva, D.a.L., Delai, I., Miranda, M.M.D., Laura, M., Montes, D., Ometto, A.R., 2012. LCA Application : The Case of the Sugar Cane Bagasse Electricity Generation in Brazil. Leveraging Technology for a Sustainable World Proceedings of the 19th CIRP Conference on Life Cycle Engineering, University of California at Berkeley, Berkeley, USA, May 23 - 25, 2012.

Smith, C., Burrows, J., Scheier, E., Young, A., Smith, J., Young, T., Gheewala, S.H., 2015. Comparative Life Cycle Assessment of a Thai Island's diesel/PV/wind hybrid microgrid. Renewable Energy 80, 85-100. doi:10.1016/j.renene.2015.01.003.

SOeS, 2015. Key energy data in France - Edition 2014 [in French]. Technical Report. Ministère de L'Ecologie du Développement durable et de L'Energie. France.

SPL Energies Réunion, 2015. Energy balance of Reunion Island 2014. [in French]. Technical Report. Reunion.

SPL Energies Réunion, 2016. Energy balance of Reunion Island 2015. [in French]. Technical Report. Reunion.

Tan, R.B., Wijaya, D., Khoo, H.H., 2010. LCI (Life cycle inventory) analysis of fuels and electricity generation in Singapore. Energy 35, 4910-4916. doi:10.1016/j.energy.2010.08.036.

Theodosiou, G., Koroneos, C., Stylos, N., 2014. Environmental impacts of the Greek electricity generation sector. Sustainable Energy Technologies and Assessments 5, 19-27. doi:10.1016/j.seta.2013.10.005.

Turconi, R., Boldrin, A., Astrup, T., 2013. Life cycle assessment (LCA) of electricity generation technologies: Overview, comparability and limitations. Renewable and Sustainable Energy Reviews 28, 555-565. doi:10.1016/j.rser.2013.08.013. 